\title{
Effect of hydrolyzed whey protein on surface morphology, water sorption, and glass transition temperature of a model infant formula
}

\author{
Grace M. Kelly, ${ }^{*} \dagger$ James A. O’Mahony, $†$ Alan L. Kelly, $†$ and Donal J. O'Callaghan* \\ *Teagasc Food Research Centre, Moorepark, Fermoy, Co. Cork, P61 C996, Ireland \\ †School of Food and Nutritional Sciences, University College Cork, Cork, T12 Y337, Ireland
}

\begin{abstract}
Physical properties of spray-dried dairy powders depend on their composition and physical characteristics. This study investigated the effect of hydrolyzed whey protein on the microstructure and physical stability of dried model infant formula. Model infant formulas were produced containing either intact (DH 0) or hydrolyzed (DH 12) whey protein, where $\mathrm{DH}=$ degree of hydrolysis (\%). Before spray drying, apparent viscosities of liquid feeds (at $55^{\circ} \mathrm{C}$ ) at a shear rate of $500 \mathrm{~s}^{-1}$ were 3.02 and $3.85 \mathrm{mPa} \cdot \mathrm{s}$ for intact and hydrolyzed infant formulas, respectively. On reconstitution, powders with hydrolyzed whey protein had a significantly higher fat globule size and lower emulsion stability than intact whey protein powder. Lactose crystallization in powders occurred at higher relative humidity for hydrolyzed formula. The Guggenheim-Anderson-de Boer equation, fitted to sorption isotherms, showed increased monolayer moisture when intact protein was present. As expected, glass transition decreased significantly with increasing water content. Partial hydrolysis of whey protein in model infant formula resulted in altered powder particle surface morphology, lactose crystallization properties, and storage stability.

Key words: hydrolyzed whey, infant formula, sorption isotherms, storage stability, surface morphology
\end{abstract}

\section{INTRODUCTION}

Whey protein hydrolysates (WPH) and whey protein isolates (WPI) are widely used sources of protein in the food industry, for example, in performance foods and infant milk formula (IMF). The IMF industry uses WPI and WPH, the latter being used for ease of digestion in infant comfort foods. Whey protein hydrolysates are used in the nutritional management of individuals unable to digest intact protein, providing complete

Received September 25, 2015.

Accepted March 29, 2016.

${ }^{1}$ Corresponding author: donal.ocallaghan@teagasc.ie nutritional requirements with positive health benefits. They have lower molecular mass and less secondary structure than WPI (Chobert et al., 1988).

Proteins play an important role in the stabilization of oil-in-water emulsions in IMF (Damodaran, 2005; McCarthy et al., 2012). Because proteins are incorporated into spray-dried food systems, it is of interest to study the effects of processing on the physical properties of resulting powders, especially in relation to storage stability and rehydration. Physicochemical changes in food powders have been related to their glass transition temperature ( $\mathbf{T}_{\mathbf{g}}$; Roos, 1995; McCarthy et al., 2013). For example, powders with low $\mathrm{T}_{\mathrm{g}}$, caused by increased moisture content, may exhibit accelerated deteriorative changes such as stickiness, caking, cohesion, and sugar crystallization.

Lactose, due to its hygroscopic nature, can readily absorb moisture, which may lead to deteriorative reactions (e.g., caking, cohesion, and crystallization) in milk powders. Previous work has explored the effects of milk proteins on the physical behavior of lactose in dairy powders (Haque and Roos, 2004; Hogan and O'Callaghan, 2010; Murphy et al., 2015). It has been shown that, as the protein:lactose ratio increases, there is a concomitant increase in $T_{g}$, making high-protein:lactose ratio powders more resistant to stickiness and crystallization (Thomas et al., 2004; McCarthy et al., 2013; Kelly et al., 2015). Netto et al. (1998) reported that the $T_{g}$ of pure protein hydrolysates depends on the source of protein, for example, casein or whey protein, as well as the degree of hydrolysis (DH), and suggested that proteins may be equally as important as sugars in altering $T_{\mathrm{g}}$. Mounsey et al. (2012) reported that stickiness of hydrolyzed sodium caseinate-lactose mixtures was affected by protein hydrolysis: intact sodium caseinate-lactose mixture was less susceptible to sticking compared with powders with hydrolyzed sodium caseinate-lactose, with the extent of protein hydrolysis having no significant effect on the stickiness behavior.

Hogan and O'Callaghan (2013) studied the effect of varying the $\mathrm{DH}$ of whey protein in protein-lactose dispersions and concluded that as DH percentage in- 
creased, hygroscopicity increased and crystallization was delayed. Recently, Murphy et al. (2015) examined the effect of partially and selectively hydrolyzed (in which $\beta$-LG was selectively hydrolyzed) proteins within a model infant formula and concluded that selectively hydrolyzed milk proteins may be successfully used to produce IMF powders with good physical characteristics. Protein ingredients require good solubility, emulsification capacity, and thermal stability when used in IMF. Stable emulsions are required to minimize surface free fat during manufacture of IMF and protect against creaming in reconstituted IMF products.

The majority of studies on hydrolyzed proteins in IMF have focused on nutritional and allergenic aspects rather than functional characteristics such as emulsification and viscosity. The significance of protein content on IMF emulsion stability has recently been reported (McCarthy et al., 2012, 2013; Murphy et al., 2015).

The objective of the present study was to compare the effects of hydrolyzed whey $(12 \% \mathrm{DH})$ compared with intact whey on the stability of model infant milk formula emulsions during processing, and also on physicochemical properties in the resultant powders. To determine emulsion stability, emulsion fat globule size (FGS) and viscosity were evaluated systematically throughout processing and reconstitution (i.e., posthomogenization, spray drying, and reconstitution). Stability of spray-dried powder was examined in relation to relative humidity $(\mathbf{R H})$.

\section{MATERIALS AND METHODS}

\section{Materials}

Intact whey protein concentrate $(80 \%$ protein by weight) and hydrolyzed whey protein concentrate $(80 \%$ protein by weight) with a $\mathrm{DH}$ value of $12 \%$ were purchased from Carbery Ingredients Ltd. (Ballineen, Co. Cork, Ireland). According to the supplier, the WPH had an average molecular weight of $5.84 \mathrm{kDa}$, with more than $70 \%$ being $>5 \mathrm{kDa}$. Edible-grade $\alpha$-lactose monohydrate was obtained from Glanbia Ingredients (Ballyraggett, Co. Kilkenny, Ireland), sunflower oil was purchased from Trilby Trading (Drogheda, Co. Louth, Ireland), and skim milk powder (SMP; consisting of intact casein and whey protein, 80:20 ratio) was purchased from Dairygold Food Ingredients (Mitchelstown, Co. Cork, Ireland).

\section{Preparation of IMF Powders}

Emulsions consisting of $11.8 \%$ (wt/wt) lactose, $2.5 \%$ (wt/wt) protein (whey:casein 60:40), and 5.7\% (wt/ wt) oil were prepared (20\% wt/wt total solids). Batches $(15 \mathrm{~kg})$ were produced as follows. Lactose powder was dissolved in preheated water $\left(\sim 70^{\circ} \mathrm{C}\right)$, using a Silverson L4RT (Silverson Machines Ltd., Waterside, Chesham, UK) mixer to aid reconstitution. Approximately $10 \%$ of the total fat was added to the batch to reduce foaming before addition of protein. The SMP was then added slowly, followed by whey protein, before addition of the remaining fat. The batches were tempered at $60^{\circ} \mathrm{C}$ and adjusted to $\mathrm{pH} 6.9$ by adding $2 \mathrm{M} \mathrm{KOH}$ and kept under high shear for $30 \mathrm{~min}$ to ensure complete hydration of the protein. The feed was subjected to heat treatment $\left(100^{\circ} \mathrm{C} \times 30 \mathrm{~s}\right)$ using a Microthermics tubular heat exchanger (model $25 \mathrm{HV}$; Raleigh, NC). The coarse emulsion was then homogenized using a LAB 60 homogenizer (APV, Lübeck, Germany) using a first-stage pressure of $13.6 \mathrm{MPa}$ and a second-stage pressure of 3.4 MPa. It was subsequently spray-dried in a pilot-scale Anhydro spray dryer (model Plant No. 3 type I KA, Copenhagen, Denmark), equipped with a 2-fluid nozzle atomization system (Type 1/8 JAC 316ss) and counterflow drying. Dryer inlet temperature was held constant at $185^{\circ} \mathrm{C}$ and outlet temperature was $80^{\circ} \mathrm{C}$.

\section{Emulsion FGS and Powder Particle Size}

Emulsion FGS was measured after homogenization and after reconstitution of powder using dynamic light scattering (Mastersizer 3000, Malvern Instruments Ltd., Malvern, UK). The optical parameters used were refractive indices of 1.46 and 1.33 for sample and dispersant, respectively, and particle absorbance of 0.001 . Product was reconstituted $(12.5 \mathrm{~g} / 100 \mathrm{~g})$ at $\sim 40^{\circ} \mathrm{C}$. The following fat globule size parameters are presented: $\mathrm{cu}-$ mulative volume diameters, $\mathrm{D}\left({ }_{\mathrm{v}}, \mathbf{0 . 1}\right)$ and $\mathrm{D}\left({ }_{\mathrm{v}}, \mathbf{0 . 9}\right)$, such that all globules below that size amount to 10 and $90 \%$, respectively, of total volume of fat globules, and volume mean diameter, $\mathbf{D}[\mathbf{4}, \mathbf{3}]$, also known as the volume moment mean, determined as

$$
D[4,3]=\frac{\sum d^{4}}{\sum d^{3}} .
$$

Powder particle size was determined by laser light scattering using a Malvern Mastersizer 3000 with the Aero S dry powder feeder unit. The powder sample was added to the standard venturi disperser with a hopper gap of $4 \mathrm{~mm}$ and then fed into the dispersion system at a feed rate of 18 to $25 \%$ to keep the laser obscuration level at 1 to $6 \%$. Compressed air at $50 \mathrm{kPa}$ was used to transport and suspend the powder particles through the optical cell and a measurement time of $10 \mathrm{~s}$ was 
used. Background measurements were made using air for $20 \mathrm{~s}$.

\section{Viscosity}

Viscosity for each formulation, before and after homogenization, was measured at $55^{\circ} \mathrm{C}$. Reconstituted product at $12.5 \%$ (wt/wt) was measured at $20^{\circ} \mathrm{C}$ using an AR-G2 controlled stress rheometer (TA Instruments, Crawley, UK), equipped with concentric cylinder geometry in shear rate sweep mode. Samples were presheared at $500 \mathrm{~s}^{-1}$ for $1 \mathrm{~min}$, followed by equilibration for $2 \mathrm{~min}$. An ascending shear rate sweep was then applied from 5 to $500 \mathrm{~s}^{-1}$ over $3 \mathrm{~min}$, followed by holding at $500 \mathrm{~s}^{-1}$ for $1 \mathrm{~min}$. The average apparent viscosity measured at 500 $\mathrm{s}^{-1}$ was used to compare the formulations.

\section{Emulsion Stability}

A LUMiSizer stability analyzer (L.U.M. GmbH, Berlin, Germany) was used to measure the separation rate (creaming rate) of hydrolyzed and intact formula at $25^{\circ} \mathrm{C}$, which operates on the basis of continuous measurement of light transmitted through a specimen over a defined length in a measurement cell. Polycarbonate sample cells were loaded with the reconstituted product ( $0.4 \mathrm{~mL}$ aliquots at $12.5 \% \mathrm{wt} / \mathrm{wt})$ and centrifuged (285 $\times g$ ) for approximately $7.2 \mathrm{~h}$, simulating approximately 3 mo of separation under normal gravity. Creaming velocity under centrifugal acceleration was determined from the evolution of light-transmission profiles over sample length at successive time intervals; that is, creaming velocity was calculated as the rate of progress of the creaming zone along the sample tube. Applying Stokes' law, the equivalent creaming velocity at normal gravity $(1 \times g)$ was calculated. The software package SepView 4.1 (L.U.M GmbH) was used for these calculations.

\section{Powder Characterization}

Water content of powders was determined using a halogen rapid moisture analyzer (HR-83 Halogen, Mettler Toledo, Greifensee, Switzerland). The samples were dried at a temperature of $105^{\circ} \mathrm{C}$ until a constant weight was attained $(<1 \mathrm{mg}$ change over $140 \mathrm{~s}$, equivalent to $\pm 0.025 \%)$. Water activity $\left(\mathbf{a}_{\mathrm{w}}\right)$ was measured with a Novasina LabMaster $\mathrm{a}_{\mathrm{w}}$ water activity meter (Novatron Scientific Ltd., West Sussex, UK). Protein content $(\mathrm{N} \times$ 6.38) was determined by macro-Kjeldahl (IDF, 2001). Fat and lactose contents were estimated from the composition of ingredients. Ash content was determined after overnight incineration at $550^{\circ} \mathrm{C}$. Tapped bulk density was measured by GEA Niro (2006) method, and surface free fat level of powders was determined by GEA Niro (2005) method, as described in detail in by Kelly et al. (2014). Microencapsulation efficiency (ME) was calculated using Eq. [1]:

$$
\mathrm{ME}=\frac{\text { Total oil }- \text { Extractable oil }}{\text { Total oil }} \times 100 .
$$

Chemical analysis of powders was carried out immediately after manufacture, in duplicate.

\section{Water Sorption Isotherms}

Water sorption isotherms were determined gravimetrically as described by (Kelly et al., 2015) using a dynamic vapor sorption (DVS) technique. Dried samples $(\sim 30 \mathrm{mg})$ were loaded into the sample pan and humidified from 0 to $90 \% \mathrm{RH}$ in increments of 10 percentage points of RH. Equilibrium was considered to be reached when the change in mass with time $(\mathrm{d} m /$ $\mathrm{d} t)$ was $<0.001 \mathrm{mg} / \mathrm{min}$ for at least $10 \mathrm{~min}$ for each step. The DVS Data Analysis Suite, which runs with an Excel add-on (Microsoft Office, 2003; Microsoft Corp., Redmond, WA), was used to graph and analyze data.

The Guggenheim-Anderson de Boer (GAB) equation (Van den Berg, 1984) was used to model water sorption isotherms and to determine the critical water content and $\mathrm{a}_{\mathrm{w}}$ :

$$
\frac{m}{m_{m}}=\frac{\mathrm{CKa}_{\mathrm{w}}}{\left(1-\mathrm{Ka}_{\mathrm{w}}\right)\left[1+\mathrm{Ka}_{\mathrm{w}}(\mathrm{C}-1)\right]},
$$

where $m$ is the moisture content ( $\mathrm{g} / 100 \mathrm{~g}$ of dry solids), $m_{m}$ is the monolayer value $(\mathrm{g} / 100 \mathrm{~g})$, and $\mathrm{C}$ and $\mathrm{K}$ are constants, $\mathrm{K}$ having units inverse to $\mathrm{a}_{\mathrm{w}}$ and $\mathrm{C}$ being dimensionless.

Bizot (1983) showed that this equation could be transformed to a quadratic equation (Eq. [3]):

$$
\frac{\mathrm{a}_{\mathrm{w}}}{m}=\alpha \mathrm{a}_{\mathrm{w}}^{2}+\beta \mathrm{a}_{\mathrm{w}}+\gamma,
$$

where parameters $\alpha, \beta$, and $\gamma$ are related to $\mathrm{C}, \mathrm{K}$, and $\mathrm{m}_{\mathrm{m}}$.

Values for the parameters $\alpha, \beta$, and $\gamma$ were determined by quadratic regression analysis of $\frac{a_{w}}{m}$ as a function of $\mathrm{a}_{\mathrm{w}}$ using DVS data; for example, over a range of $\mathrm{a}_{\mathrm{w}}$ from 0 to 0.4. The solution to equations [2] and [3] give the values for $m_{m}, \mathrm{~K}$, and $\mathrm{C}$ as follows: 


$$
\begin{gathered}
m_{m}=\frac{1}{\sqrt{\beta^{2}-4 \alpha \gamma}}, \\
\mathrm{K}=\frac{\beta-\left(\frac{1}{m_{m}}\right)}{-2 \gamma}, \\
\mathrm{C}=\frac{1}{m_{m} \mathrm{~K} \gamma} .
\end{gathered}
$$

\section{Differential Scanning Calorimetry}

Powders were stored at $\sim 22^{\circ} \mathrm{C}$ in vacuum desiccators containing $\mathrm{P}_{2} \mathrm{O}_{5}(0 \% \mathrm{RH})$ for $14 \mathrm{~d}$. Samples were then placed in vacuum desiccators containing $\mathrm{LiCl}$, $\mathrm{CH}_{3} \mathrm{COOK}, \mathrm{MgCl}_{2}, \mathrm{~K}_{2} \mathrm{CO}_{3}$, and $\mathrm{Mg}\left(\mathrm{NO}_{3}\right)_{2}$, giving $\mathrm{RH}$ values of $11.4,23.1,33.2,44.1$, and $54.4 \%$, respectively, with $\mathrm{a}_{\mathrm{w}}$ being $0.01 \times \% \mathrm{RH}$. A differential scanning calorimeter (DSC Q2000, TA Instruments, Crawley, UK) was used to determine $T_{\mathrm{g}}$. Samples (8-12 mg) were scanned in hermetically sealed aluminum pans and subjected to heating from 0 to $100^{\circ} \mathrm{C}$ at $5^{\circ} \mathrm{C} /$ min, followed by cooling to $0^{\circ} \mathrm{C}$ at $10^{\circ} \mathrm{C} / \mathrm{min}$, and then heating at $5^{\circ} \mathrm{C} / \mathrm{min}$ from 0 to $160^{\circ} \mathrm{C}$. Using the $\mathrm{TA}$ Universal Analysis software, the onset ( $\mathrm{T}_{g}$ onset) and midpoint $\left(\mathrm{T}_{g}\right.$ mid) glass transition temperatures were determined. An empty aluminum pan was used as a reference. The differential scanning calorimeter was calibrated by means of indium standards, and dry nitrogen $(50 \mathrm{~mL} / \mathrm{min})$ was used as the purge gas.

\section{Scanning Electron Microscopy}

Powders were stored at $0 \%$ and $54.4 \% \mathrm{RH}$ before scanning electron microscopy observation. Samples were imaged using a field emission scanning electron microscope (FE-SEM; Zeiss Supra Gemini, Darmstadt, Germany) at $2.00 \mathrm{kV}$. Samples were mounted on double-sided carbon tape, attached to scanning electron microscope stubs, and then sputter-coated with chromium (K550X, Emitech, Ashford, UK). Representative micrographs were taken at $1,000 \times$ and $5,000 \times$ magnification to visualize surface morphology.

\section{Statistical Analysis}

Formulation manufacture and spray-drying trials were carried out in triplicate, with trials for each replicate being carried out in random order, as generated by Design Expert Version 7.1.6 (Stat Ease, Minneapolis, MN). One-way ANOVA was used with Minitab 15
(Minitab Ltd., Coventry, UK) to determine significant differences between powders by Fisher's one-way multiple comparison test. Results were deemed statistically significant if $P<0.05$.

\section{RESULTS AND DISCUSSION}

\section{Emulsion FGS and Viscosity}

During processing, emulsion FGS was monitored after homogenization (Table 1). The HF powder had significantly $(P<0.05)$ higher FGS $\left(\mathrm{D}[4,3]\right.$, and $\left.\mathrm{D}\left({ }_{\mathrm{v}}, 0.9\right)\right)$ compared with IF, reflecting a bimodal size distribution (Figure 1). For HF, homogenization did not reduce particle size to below the desired mean FGS of $<1 \mu \mathrm{m}$ (Sheu and Rosenberg, 1995), which has negative implications for emulsion stability. The FGS for HF was higher because hydrolyzed proteins, due to the presence of short peptides, are not as efficient as emulsifiers and have reduced stabilizing properties compared with intact proteins (Agboola and Dalgleish, 1996). The main difficulties arising from using hydrolyzed proteins are (1) that they are less likely to adsorb to the fat globule surface due to their poor hydrophobicity; (2) the least hydrophobic peptides are likely to be the most charged in solution, resulting in reduced charge of oil droplets; and (3) if the peptides are short, then steric stabilization is less likely (Singh and Dalgleish, 1998). However, Drapala et al. (2016) showed that WPH emulsions could be produced with improved thermal stability, without changes in FGS, by conjugation of WPH with carbohydrate (maltodextrin), due to increased steric and electrostatic repulsion. Emulsifiers such as lecithin and monoglycerides are commonly added to formulas with hydrolyzed protein to aid emulsification and hence reduce FGS during homogenization (Drapala et al., 2015).

In comparing apparent viscosity of formulations before and after homogenization, no significant difference $(P>0.05)$ was observed for IF, and a significant $(P$ $<0.05)$ increase in viscosity was found in HF posthomogenization (Table 1). In this study, HF posthomogenization emulsions, which had higher FGS compared with IF, had higher viscosity than IF emulsions. This is consistent with other studies in which emulsions with reduced FGS have been shown to have reduced viscosity (Floury et al., 2000; Maher et al., 2014). Another possible reason for increased FGS of HF is that it has a higher mineral content, which has been shown to cause increased protein aggregation (Figure 1) and, thus, increased viscosity (Barbut, 1995; Murphy et al., 2015). Singh and Dalgleish (1998) showed that increasing $\mathrm{DH}(8-45 \%)$ in hydrolyzed whey proteins resulted 
in increased aggregation, with the most stable emulsions being similar to the $\mathrm{DH}$ content of the hydrolyzed protein used in the current study.

\section{Powder Reconstitution Properties}

Powders were reconstituted to $12.5 \%$ (wt/wt) before analysis, to reflect solids content in a typical reconstituted infant formula. No significant difference $(P$ $>0.05)$ was found between the reconstituted $\mathrm{D}[4,3]$ and the post-homogenization $\mathrm{D}[4,3]$ for IF (Table 1), showing that atomization had no effect on FGS. For $\mathrm{HF}$, the reconstituted $\mathrm{D}[4,3]$ was lower than that of the post-homogenization $\mathrm{D}[4,3]$, indicating that a further homogenization effect occurred during atomization, producing a monomodal particle size distribution (Table 1; data not shown). This is a desirable result, because a reconstituted powder with high FGS, as for HF post-homogenization, would separate rapidly upon rehydration. A reduction in FGS after atomization can occur with 2-fluid-nozzle atomization due to the turbulence generated by the high shear forces between the liquid surface and high velocity air. McCarthy et al. (2012), in a study using the same atomizer type (2-fluid nozzle) observed significant FGS reduction for model infant formula. In the present study, the reduction in FGS (from a high initial value of 32.3 to $1.31 \mu \mathrm{m}$ ) may be related to greater flexibility or weaker interfacial layer dominated by peptides rather than intact proteins, and it may also be that atomization is effective at reducing the size of large fat globules.

Viscosities of reconstituted IF and HF powders were not significantly different $(P>0.05$; Table 1$)$. A small decrease in viscosity was observed in HF on reconstitution compared with the post-homogenization measurement, resulting in the reconstituted emulsions having similar viscosity. Again, this slight reduction in viscosity may be due to the decreased FGS. These minor effects are due to a combination of TS, temperature, and FGS; analysis of viscosity before homogenization was carried out at a higher temperature and TS content $\left(55^{\circ} \mathrm{C}\right.$ and $20 \%$ TS) compared with reconstituted product $\left(20^{\circ} \mathrm{C}\right.$ and $12.5 \% \mathrm{TS}$ ). With regard to the lack of large differences in viscosity at different steps in the experiment, it should be noted that Dinkov et al. (2008) found that the viscosity of whole milk increased from $\sim 2.0 \mathrm{mPa} \cdot \mathrm{s}$ at $20 \%$ TS and $50^{\circ} \mathrm{C}$ to $\sim 2.5 \mathrm{mPa} \cdot \mathrm{s}$ at $11.2 \%$ TS and $20^{\circ} \mathrm{C}$. Thus, in this study, we can infer that the effect of decreasing TS (reducing viscosity) largely outweighed the effect of a lower temperature (increasing viscosity).

Differences in emulsion stability were observed in the separation rate (creaming rate and cream layer height as measured by analytical centrifugation) of reconstituted powders in an accelerated storage test over 7.5 
$\mathrm{h}$, which simulated 3 mo of storage under gravity. The creaming rate and cream layer height were significantly $(P<0.05)$ higher for HF than for IF emulsions, indicative of lower storage stability (Lajoie et al., 2001). This is consistent with Stokes' law, where particles of greater diameter separate from the continuous phase at a faster rate than smaller particles. Achieving an FGS $<1 \mu \mathrm{m}$ is an important target for increasing emulsion stability and reducing free fat level in powders (Sheu and Rosenberg, 1995; Hogan et al., 2001). An FGS of $0.64 \mu \mathrm{m}$ was observed for IF; however, FGS was significantly $(P$ $<0.05)$ greater for HF, with a value of $1.31 \mu \mathrm{m}$. When using hydrolyzed proteins, FGS could be reduced by using different processing conditions; for example, the use of emulsifiers and higher homogenizing pressure and passes (Danviriyakul et al., 2002; Keogh et al., 2006).

\section{Powder Properties}

Both powders had similar protein, lactose, and fat contents. Moisture content was 2.2 and $1.84 \%$ (wt/wt) for IF and HF, respectively, following drying (Table 2). A significantly $(P<0.05)$ lower $\mathrm{a}_{\mathrm{w}}$ of 0.15 was observed for HF compared with that of 0.19 for IF. The ash content of HF was significantly $(P<0.05)$ higher than that of IF, reflecting the higher mineral composition in hydrolyzed whey starting material. Mean powder particle size, $\mathrm{D}[4,3]$, and tapped bulk densities of pow-
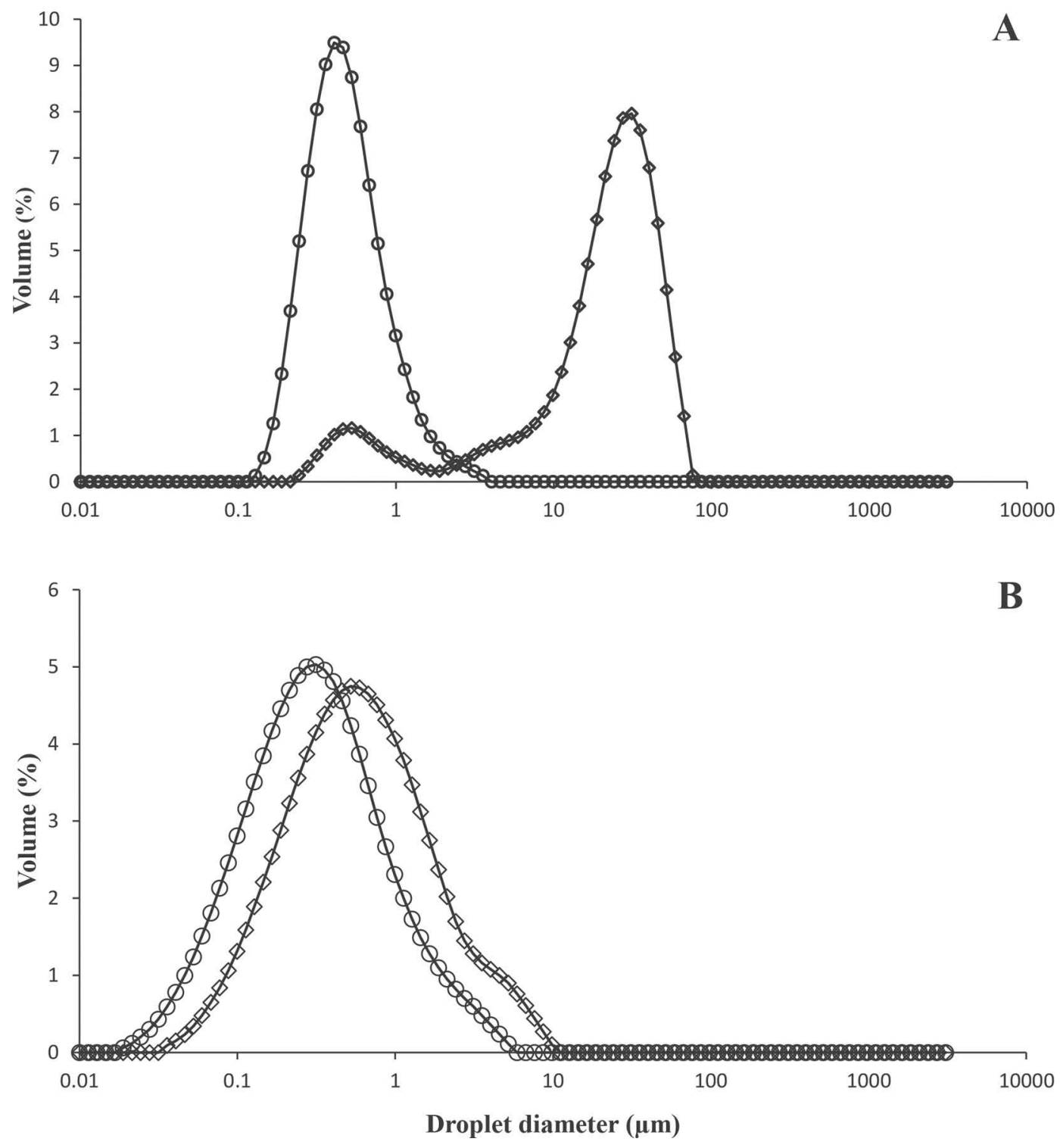

Figure 1. Fat globule size distribution profile of emulsions formulated with intact $(\bigcirc)$ and hydrolyzed whey $(\diamond)$ protein, after homogenization (A) and on reconstitution (B). The y-axis gives percent of total distribution per size interval (18 size intervals per decade). 
Table 2. Composition ${ }^{1}(\mathrm{~g} / 100 \mathrm{~g})$ and water activity $\left(\mathrm{a}_{\mathrm{w}}\right)$ of model infant formula powders containing intact (IF) or hydrolyzed (HF) whey protein

\begin{tabular}{lcccccc}
\hline Formula & Protein & Lactose & Fat & Moisture & Ash & $\mathrm{a}_{\mathrm{w}}$ \\
\hline $\mathrm{IF}$ & $12.4 \pm 0.27^{\mathrm{a}}$ & 56.8 & 27.6 & $2.20 \pm 0.23^{\mathrm{a}}$ & $1.86 \pm 0.03^{\mathrm{a}}$ & $0.19 \pm 0.00^{\mathrm{b}}$ \\
$\mathrm{HF}$ & $12.2 \pm 0.18^{\mathrm{a}}$ & 57.0 & 27.7 & $1.84 \pm 0.27^{\mathrm{a}}$ & $2.15 \pm 0.05^{\mathrm{b}}$ & $0.15 \pm 0.00^{\mathrm{a}}$ \\
\hline
\end{tabular}

$\overline{\mathrm{a}, \mathrm{b}}$ Values within a column not sharing a common letter differ significantly $(P<0.05)$.

${ }^{1}$ Results are shown as mean \pm SD. Values for fat and lactose were calculated from composition of ingredients, and for this reason SD is omitted.

ders were not significantly $(P>0.05)$ different (Table $3)$. Generally, increasing viscosity gives rise to larger powder particles (Hogan et al., 2001); however, in this study the difference in viscosity was not enough to have a significant effect (Tables 1 and 3). Solvent-extractable free fat content of powders was significantly $(P$ $<0.05$ ) lower in IF compared with HF powder (Table $3)$. We suggest that this is due to the higher emulsification capacity of intact whey protein. Also, FGS for reconstituted IF was less than that for HF (Table 1), meaning that the smaller oil droplets formed during spray-drying are more efficiently embedded within the powder wall matrix, and thus less likely to be extracted by solvent during testing (Maher et al., 2015). A significantly lower FGS was achieved when HF was reconstituted, suggesting that atomization decreases FGS significantly; however, FGS was still significantly larger compared with that of reconstituted IF. Atomization may have led to rupture of the fat globule; however, inefficient re-emulsification occurred, leading to a higher solvent-extractable free fat content. Consequently, this had a positive effect on microencapsulation efficiency, which was significantly higher $(P<0.05)$ in IF (Table $3)$. It is desirable to maximize microencapsulation efficiency so that surface free fat is minimized in powders, which increases their hydrophobicity, reduces solubility in water, and promotes lipid oxidation (Písecký, 1997). There are suggestions in the literature as to how this might be achieved, for example, by altering molecular size, processing conditions, emulsifiers, and protein source (Singh and Dalgleish, 1998; Keogh et al., 2006; Kelly et al., 2014). Singh and Dalgleish (1998) reported that hydrolyzed whey protein with an average molecular mass of $0.52 \mathrm{kDa}$ and a $\mathrm{DH}$ of $20 \%$ was sufficient to produce a monodisperse emulsion with $\mathrm{D}[4,3]<1$ $\mu \mathrm{m}$, with the current study using an average molecular weight of $5.84 \mathrm{kDa}$. The homogenization mechanisms used in the study of Singh and Dalgleish (1998) were different from those used here. In the present study, a 2 -stage valve homogenizer was used, whereas Singh and Dalgleish (1998) used a microfluidizer through which the emulsion was passed multiple times. In this context, it should be noted also that $\mathrm{DH}$ is a crude predictor of hydrolysis profile; that is, very different molecular weight profiles may occur for the same $\mathrm{DH}$, which would result in different emulsification properties.

\section{Differential Scanning Calorimetry}

As expected, the $T_{\mathrm{g}}$ and $\mathrm{T}_{\mathrm{cr}}$ values of powders (Table 4) decreased with increasing $a_{w}$, due to the increased plasticization effects with increasing water content (Haque and Roos, 2004; Omar and Roos, 2007). Glass transition temperature was not significantly $(P>0.05)$ different for HF compared with IF, except at $\mathrm{a}_{\mathrm{w}}=0.23$ (Table 4).

Powders with low $\mathrm{T}_{\mathrm{g}}$ are more likely to present problems with sticking or caking. Stickiness occurs at a critical viscosity of $10^{7} \mathrm{~Pa} \cdot \mathrm{s}$ (Bellows and King, 1973; Downton et al., 1982) at temperatures of 10 to $20^{\circ} \mathrm{C}$ above $\mathrm{T}_{\mathrm{g}}$ (Roos and Karel, 1991). Therefore, the temperature of the powder surface during spray drying should be 10 to $20^{\circ} \mathrm{C}$ below $\mathrm{T}_{\mathrm{g}}$ to prevent stickiness. Netto et al. (1998) and Zhou et al. (2014) reported that moisture-induced decreases in $\mathrm{T}_{\mathrm{g}}$ of lactose-free, hydrolyzed protein powders are greater than those for nonhydrolyzed powders. Although such findings suggest that hydrolysis of proteins increases their sensitivity to the

Table 3. Physical properties ${ }^{1}$ of model infant formula powders containing intact (IF) and hydrolyzed (HF) whey protein

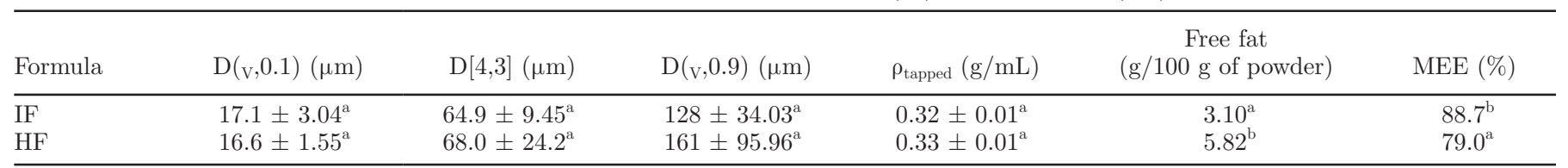

${ }^{\mathrm{a}, \mathrm{b}}$ Values within a column not sharing a common letter differ significantly $(P<0.05)$.

${ }^{1}$ Cumulative volume diameters, $\mathrm{D}(\mathrm{v}, 0.1)$ and $\mathrm{D}(\mathrm{v}, 0.9)$, such that all globules below that size amount to 10 and $90 \%$, respectively, of total volume of fat globules, and volume mean diameter, $\mathrm{D}[4,3]$, also known as the volume moment mean, determined as $D[4,3]=\frac{\sum d^{4}}{\sum d^{3}}$. $\rho_{\text {tapped }}=$ tapped bulk
density; values given as mean $\pm \mathrm{SD} ; \mathrm{MEE}=$ microencapsulation efficiency. 
plasticizing effects of moisture, presumably due to the greater mobility of shorter peptide chains, the $T_{g}$ values reported were for pure protein powders rather than the mixed protein-lactose-fat systems of the present study.

Molecular weight is related to $\mathrm{T}_{\mathrm{g}}$, with a low molecular weight decreasing the $\mathrm{T}_{\mathrm{g}}$ value (Levine and Slade, 1986). Glass transition occurs at higher temperatures for proteins than for disaccharide sugars, as the plasticizing effects of moisture and heat are less pronounced in large macromolecules, with the effect that material relaxation and viscoelastic change are diminished in the presence of proteins (Hogan et al., 2010). Lactose, which was present at a constant level $(\sim 57 \% \mathrm{wt} / \mathrm{wt})$, was likely the dominant influence on $\mathrm{T}_{\mathrm{g}}$. rather than the relatively minor contribution of proteins. Zhou and Roos (2011) showed that delays in crystallization were dependent on protein type, but that $\mathrm{T}_{\mathrm{g}}$ was not significantly affected, by either type or molecular weight of proteins. Netto et al. (1998) and Mounsey et al. (2012) reported that hydrolyzed casein did not significantly lower $T_{g}$ in different hydrolyzed protein powders. In the current study, $\mathrm{T}_{\mathrm{g}}$ did not differ significantly $(P>0.05)$ between model infant formula powders with intact and hydrolyzed whey. It would appear that, at the proteinor peptide-to-lactose ratio examined, it is lactose, rather than proteins, that determines the glass transition behavior (Bhandari and Howes, 1999). A recent study of $\mathrm{T}_{\mathrm{g}}$ in IMF examined selectively hydrolyzed proteins and concluded that $\mathrm{T}_{\mathrm{g}}$ was not affected by hydrolysis (Murphy et al., 2015).

In the range of $\mathrm{a}_{\mathrm{w}}$ levels from 0.1 to $0.33, \mathrm{~T}_{\mathrm{cr}}$ was not significantly lower for IF compared with HF (Table 4). At an $\mathrm{a}_{\mathrm{w}}$ of $0.44, \mathrm{~T}_{\mathrm{cr}}$ was considerably lower for IF than for HF, which is consistent with the DVS results in Figure 2, in which IF was seen to crystallize much more readily than HF. Hydrolyzed whey has been shown to delay crystallization in lactose-protein dispersions (Hogan and O'Callaghan, 2013); however, hydrolyzed casein was shown to have no effect on crystallization (Mounsey et al., 2012). We also observed a larger FGS in HF after homogenization compared with the IF emulsion. The smaller fat globules in IF posthomogenization may have provided more surface area for adsorption of protein, thus reducing the concentration of protein in the continuous phase, and thus the protein-to-lactose ratio, and consequently the lactose molecules would be freer to rearrange and crystallize upon heating (Maher et al., 2014).

\section{Sorption Isotherms}

Powder composition and environmental $\mathrm{RH}$ play an important role in glass transition and lactose crystallization behavior of amorphous powders. These, in turn, directly affect functional characteristics such as flowability, stickiness, caking, and storage stability (Shrestha et al., 2008). Sorption isotherms (0-90\% RH) of model infant formulas, containing intact and hydrolyzed whey, are shown in Figure 2, displaying different water sorption characteristics. As fat does not absorb water, the results are presented on an SNF basis (Kelly et al., 2014).

Several distinct stages can be observed on the isotherms. In both formulas, sorption of water from 0 to $30 \% \mathrm{RH}$ (i.e., below $\mathrm{T}_{\mathrm{g}}$ ) occurred at a rate of 1.3 and $1.1 \mathrm{~g} / 100 \mathrm{~g}$ per increase in $\mathrm{RH}$ for IF and HF, respectively. Maher et al. (2015) and Burnett et al. (2006) suggested that this occurs without change in structure and is mostly due to surface adsorption. It was postulated that $\mathrm{HF}$ would absorb more moisture during the initial stages of water sorption; Hogan and O'Callaghan (2013) and Mounsey et al. (2012) have shown that, as percentage DH increases, there is a concomitant increase in moisture sorption in the lower $\mathrm{RH}$ range, due to more available sites for moisture molecules to associate with; however, these studies only showed sorption isotherms for nonfat dispersions containing protein and lactose.

At 30 to $40 \%$ RH, we detected an increase in the rate of moisture sorption to 3.15 and $3.7 \mathrm{~g} / 100 \mathrm{~g}$ for IF and $\mathrm{HF}$, respectively, indicative of water moving into the bulk of the powder as it approached a glass transition

Table 4. Glass transition $\left(\mathrm{T}_{\mathrm{g}}\right)$ and crystallization temperatures $\left(\mathrm{T}_{\mathrm{cr}}\right)$ of intact $(\mathrm{IF})$ and hydrolyzed (HF) whey model infant formulas humidified at different water activities ( $\mathrm{a}_{\mathrm{w}}$; mean values $\pm \mathrm{SD}$ for triplicate samples)

\begin{tabular}{|c|c|c|c|c|c|c|c|c|}
\hline \multirow[b]{2}{*}{$a_{w}$} & \multicolumn{2}{|c|}{$\mathrm{T}_{\mathrm{g}}$ onset $\left({ }^{\circ} \mathrm{C}\right)$} & \multicolumn{2}{|c|}{$\mathrm{T}_{\mathrm{g}}$ mid } & \multicolumn{2}{|c|}{$\mathrm{T}_{\mathrm{cr}}$ onset } & \multicolumn{2}{|c|}{$\mathrm{T}_{\text {cr }}$ peak } \\
\hline & IF & $\mathrm{HF}$ & IF & $\mathrm{HF}$ & IF & $\mathrm{HF}$ & IF & $\mathrm{HF}$ \\
\hline 0 & $62.7 \pm 2.46^{\mathrm{a}}$ & $68.6 \pm 2.93^{\mathrm{a}}$ & $67.6 \pm 2.49^{\mathrm{a}}$ & $74.5 \pm 2.77^{\mathrm{b}}$ & $121 \pm 1.96^{\mathrm{a}}$ & $131 \pm 5.27^{\mathrm{b}}$ & $124 \pm 1.68^{\mathrm{a}}$ & $136 \pm 6.10^{\mathrm{b}}$ \\
\hline 0.23 & $52.4 \pm 1.08^{\mathrm{b}}$ & $48.8 \pm 0.24^{\mathrm{a}}$ & $57.5 \pm 1.46^{\mathrm{b}}$ & $54.1 \pm 0.46^{\mathrm{a}}$ & $110 \pm 2.76^{\mathrm{a}}$ & $110 \pm 4.74^{\mathrm{a}}$ & $112 \pm 3.17^{\mathrm{a}}$ & $114 \pm 6.01^{\mathrm{a}}$ \\
\hline 0.33 & $36.5 \pm 0.37^{\mathrm{a}}$ & $36.7 \pm 0.64^{\mathrm{a}}$ & $39.7 \pm 0.16^{\mathrm{a}}$ & $40.0 \pm 0.67^{\mathrm{a}}$ & $91.9 \pm 3.46^{\mathrm{a}}$ & $91.4 \pm 1.22^{\mathrm{a}}$ & $93.3 \pm 3.39^{\mathrm{a}}$ & $95.4 \pm 1.28^{\mathrm{a}}$ \\
\hline 0.44 & $14.2 \pm 0.69^{\mathrm{a}}$ & $20.0 \pm 1.57^{\mathrm{b}}$ & $18.5 \pm 0.76^{\mathrm{a}}$ & $23.0 \pm 1.36^{\mathrm{b}}$ & $55.4 \pm 2.96^{\mathrm{a}}$ & $73.1 \pm 3.86^{\mathrm{b}}$ & $56.2 \pm 2.90^{\mathrm{a}}$ & $75.3 \pm 3.61^{\mathrm{b}}$ \\
\hline
\end{tabular}

\footnotetext{
${ }^{\mathrm{a}, \mathrm{b}}$ Values within a powder type (HF vs. IF) and within a row with different superscripts for a single parameter (onset, mid-point, or peak) differ
} significantly $(P<0.05)$. 


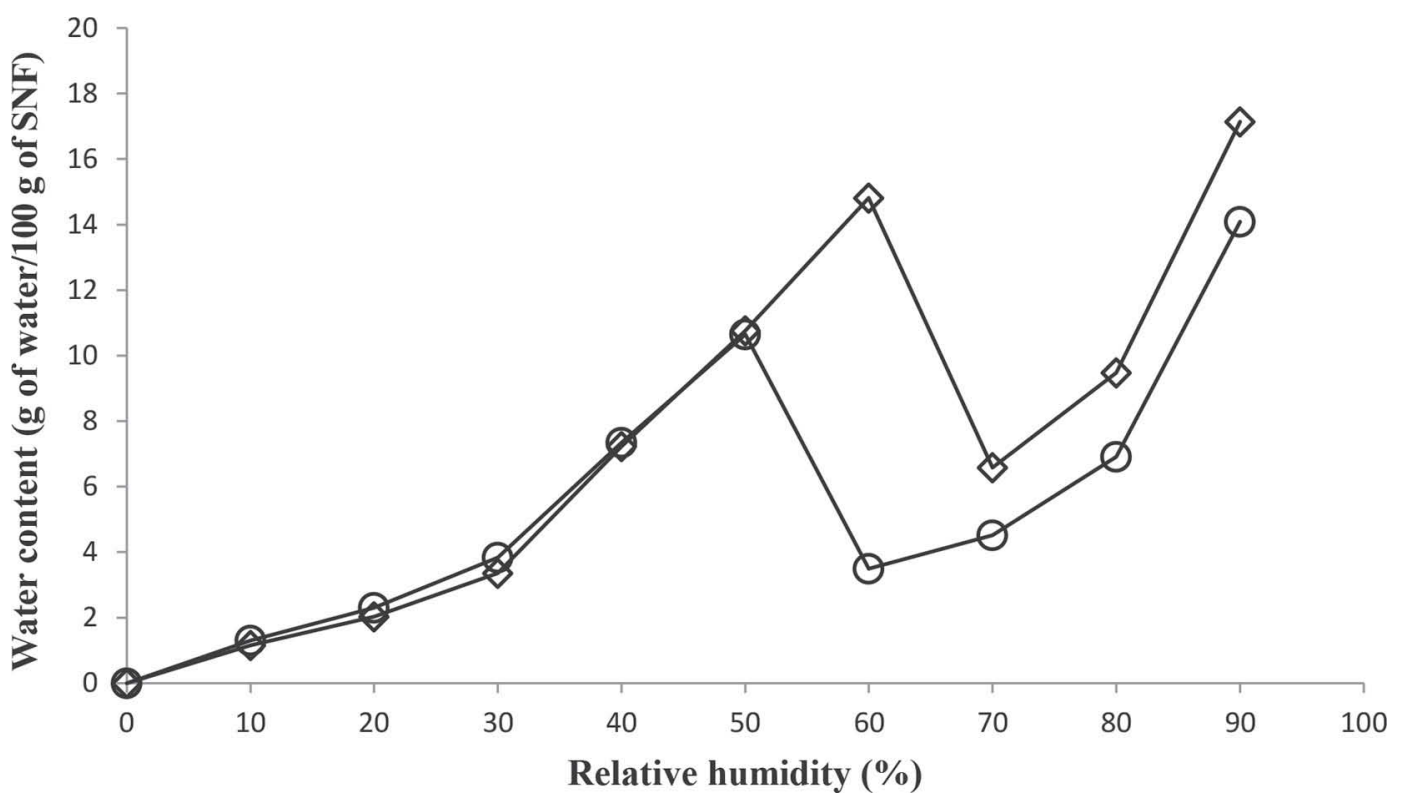

Figure 2. Moisture sorption isotherms for powders with intact $(\bigcirc)$ and hydrolyzed whey $(\diamond)$ protein. Powder moisture is expressed on an SNF basis.

region before crystallization. The dramatic influence of RH on glass transition, even at ambient temperatures, is confirmed by Table 4, showing $\mathrm{T}_{\mathrm{g}}$ approaching $25^{\circ} \mathrm{C}$ at $\mathrm{RH}$ between 33 and $44 \%$ for powders. Crystallization develops at temperatures above $\mathrm{T}_{\mathrm{g}}$ as amorphous materials relax to their more thermodynamically stable state.

Crystallization is identified by a sharp decrease in mass at some RH (Burnett et al., 2004; Kelly et al., 2014), as sorbed water is expelled during crystallization, which occurred for both powders upon humidification $(0-90 \% \mathrm{RH})$. In the isotherms shown in Figure 2 , the $\mathrm{RH}$ value at which the mass was observed to be lower than the directly preceding equilibrated mass value $\left(\mathbf{R H}_{\mathbf{c}}\right)$ is taken as an indication of completion of crystallization. In this study, $\mathrm{RH}_{\mathrm{c}}$ was higher for $\mathrm{HF}$ compared with IF (Figure 2), at 70 and $60 \% \mathrm{RH}$, respectively. This delay in crystallization in $\mathrm{HF}$ powder in relation to $\mathrm{RH}$ was confirmed by DSC results (Table 4), where crystallization temperatures were higher for $\mathrm{HF}$ at any RH. Examination of the DVS data in terms of time (min) showed that HF equilibrated and crystallized at a faster rate compared with IF, $\sim 440 \mathrm{~min}$ and $\sim 980$ min, respectively (data not shown). This means that HF powder is more stable to crystallization during storage.

A reduction in mass of sorbed water from approximately 10.2 to $2.9 \mathrm{~g} / 100 \mathrm{~g}$ and from 14.2 to $6.1 \mathrm{~g} / 100$ $\mathrm{g}$ due to crystallization of amorphous lactose was observed for IF and HF, respectively (Figure 2). After crystallization, the uptake of water increased to $\sim 13.4$ and $\sim 16.6 \mathrm{~g} / 100 \mathrm{~g}$ at $90 \% \mathrm{RH}$ for IF and HF, respectively. Maximum water sorption occurred more slowly for IF than for $\mathrm{HF}(\sim 1,465 \mathrm{~min}$ and $\sim 439 \mathrm{~min})$; this significant difference in equilibration time may be explained by the increase in hydrophilic charged peptides and AA due to hydrolysis, leading to rapid sorption of water molecules in HF powder (Mahmoud et al., 1992). Water diffusion increases in polar hydrophilic matrices (Palzer, 2010) and has been shown to increase with increasing water activity up to the point of lactose crystallization in skim and whole milk powder (Murrieta-Pazos et al., 2011) and hydrolyzed protein-lactose dispersions (Hogan and O'Callaghan, 2013, Mounsey et al., 2012).

The GAB monolayer $\left(m_{m}\right)$ values were 1.5 and 1.95 $\mathrm{g}$ of water $/ 100 \mathrm{~g}$ of solids, corresponding to 15.8 and 18.4\% RH for HF and IF powders, respectively (Table $5)$.

\section{Scanning Electron Microscopy}

Powders were imaged following equilibration at 0 and $54.4 \% \mathrm{RH}$ (Figure 3) to show the effect of $\mathrm{RH}$ on powder surface morphology. At $0 \% \mathrm{RH}$ (before lactose crystallization), IF and HF powders appeared similar in shape and structure and had a smooth surface (Figure 3; A and E). Powders examined at a higher magnification showed similarities in wall structure Figure 3; B and F). In contrast, both powders stored at $54.4 \% \mathrm{RH}$ (after lactose crystallization) were noticeably rougher, possibly due to protruding lactose crystals (Figure 3; C 
Table 5. Guggenheim-Anderson-de Boer (GAB) isotherm constants C, K, and monolayer value $\left(m_{m}\right)$ of model infant formula powders containing intact (IF) and hydrolyzed (HF) whey protein powders ${ }^{1}$

\begin{tabular}{lccccccc}
\hline Formula & $\alpha$ & $\beta$ & $\gamma$ & $\mathrm{K}$ & $\mathrm{C}$ & $m_{m}$ & $\mathrm{RMSE}$ \\
\hline $\mathrm{IF}$ & -0.71 & 0.25 & 0.07 & 1.87 & 4.22 & 2.04 & 0.97 \\
$\mathrm{HF}$ & -1.04 & 0.37 & 0.07 & 2.00 & 5.00 & 1.48 & 0.99 \\
\hline
\end{tabular}

${ }^{1}$ The water activity $\left(\mathrm{a}_{\mathrm{w}}\right)$ range of powders was 0.1 to 0.4 for all experimental data; 4 data points were taken for all powders. The terms $\mathrm{C}, \mathrm{K}$, and $m_{m}$ (g of water $/ 100 \mathrm{~g}$ of dry weight) are derived from constants $\alpha, \beta$, and $\gamma$. RMSE $=$ root mean square error.
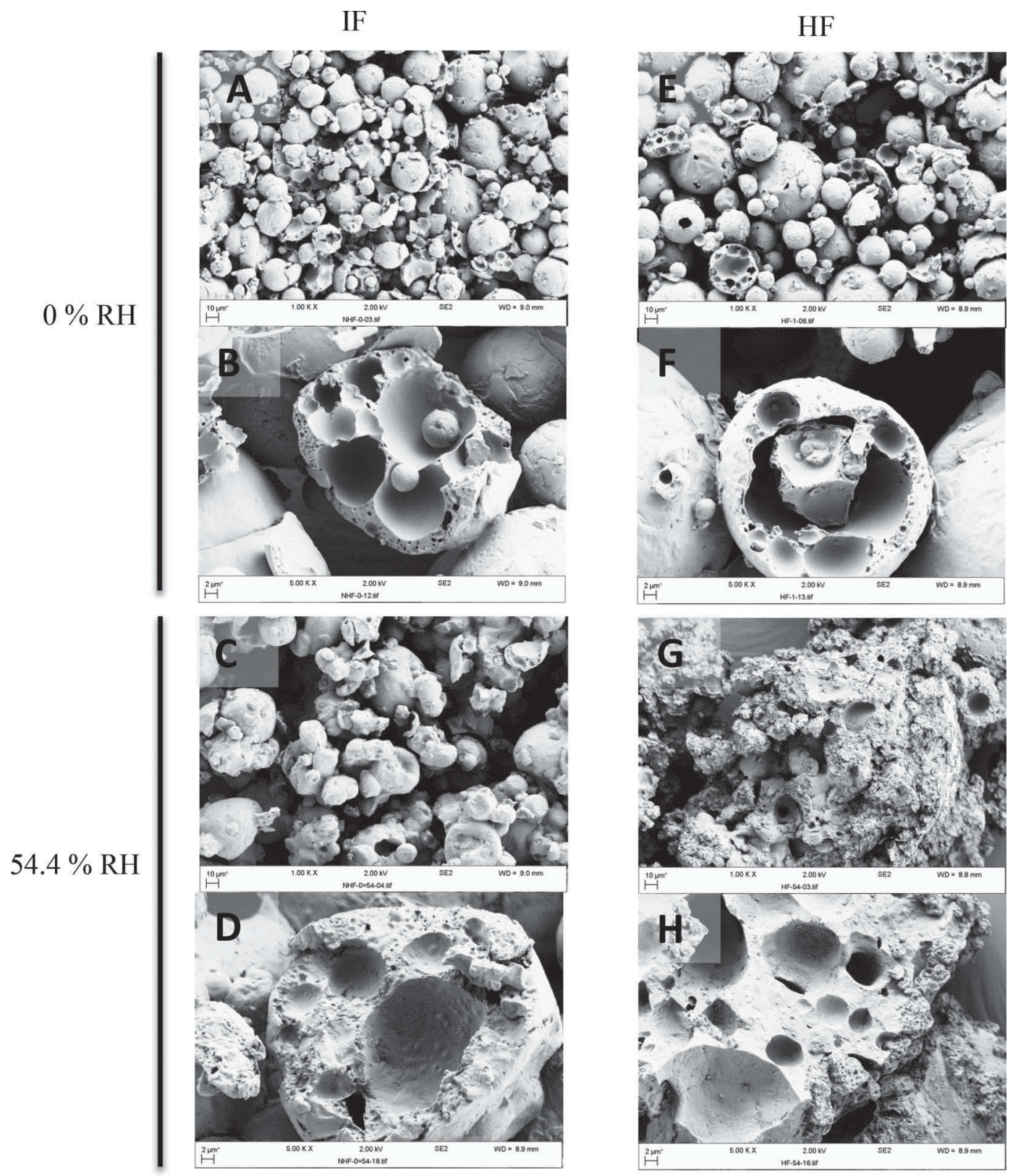

Figure 3. Scanning electron microscopy images of infant formula powders containing intact (IF) whey protein powder (A and B, pre-crystallization, low and high magnification; C and D, post-crystallization, low and high magnification) and hydrolyzed (HF) whey protein powders ( $\mathrm{E}$ and $\mathrm{F}$, pre-crystallization, low and high magnification; $\mathrm{G}$ and $\mathrm{H}$, post-crystallization, low and high magnification). Scale bar indicates $10 \mu \mathrm{m}$ for low magnification and $2 \mu \mathrm{m}$ for high magnification. 
and $\mathrm{G}$ ). At the higher magnification, it was apparent that $\mathrm{HF}$ had a noticeably rougher surface compared with IF (as is evident in Figure 3; G), suggesting that low-molecular-mass amorphous proteins are susceptible to plasticization and deformation (Netto et al., 1998). It is proposed that the high proportion of peptides $<1$ $\mathrm{kDa}$ contributed significantly to the material behavior of these powders.

\section{CONCLUSIONS}

Model IMF powders were successfully produced using intact and hydrolyzed whey protein ingredients with no added emulsifiers. The composition of model IMF emulsions had a significant effect on their physical stability throughout processing. By changing the whey protein source from intact to hydrolyzed whey protein, emulsions had larger fat globule sizes and were less stable to creaming. Spray-dried HF had higher free fat and FGS in reconstituted emulsion. A large FGS had a negative effect on emulsion stability, with creaming rate and cream layer height being significantly higher for $\mathrm{HF}$ than for IF. A lower $\mathrm{RH}_{\mathrm{c}}$ was observed for IF, which is indicative of a higher susceptibility to crystallization, conducive to a shorter shelf life compared with HF. The glass transition was affected primarily by lactose level rather than protein type. This research has shown that the use of hydrolyzed whey protein in IMF reduces emulsion stability but increases the storage stability in terms of lactose crystallization of the spraydried emulsion. However, higher free fat associated with HF powder would lead to increased lipid oxidation and reduced flowability.

\section{ACKNOWLEDGMENTS}

The authors acknowledge Deirdre Kennedy from National Food Imaging Centre (Teagasc Food Research Centre, Moorepark, Co. Cork, Ireland) for scanning electron microscope images. The authors also acknowledge the financial assistance of the Walsh Fellowship funding by Teagasc, Carlow, Ireland.

\section{REFERENCES}

Agboola, S. O., and D. G. Dalgleish. 1996. Enzymatic hydrolysis of milk proteins used for emulsion formation. 1. Kinetics of protein breakdown and storage stability of the emulsions. J. Agric. Food Chem. 44:3631-3636.

Barbut, S. 1995. Effect of sodium level on the microstructure and texture of whey protein isolate gels. Food Res. Int. 28:437-443.

Bellows, R. J., and C. J. King. 1973. Product collapse during freeze drying of liquid foods. AIChE Symp. Ser. 69:33-41.

Bhandari, B. R., and T. Howes. 1999. Implication of glass transition for the drying and stability of dried foods. J. Food Eng. 40:71-79.
Bizot, H. 1983. Using the GAB model to construct sorption isotherms. Pages 43-54 in Physical Properties of Foods. F. E. R. Jowitt, B. Hallström, H. F. T. Meffert, W. E. L. Spiess, and G. Vos, ed. Applied Science Publishers, London, UK.

Burnett, D. J., F. Thielmann, and J. Booth. 2004. Determining the critical relative humidity for moisture-induced phase transitions. Int. J. Pharm. 287:123-133.

Burnett, D. J., F. Thielmann, T. Sokoloski, and J. Brum. 2006. Investigating the moisture-induced crystallization kinetics of spraydried lactose. Int. J. Pharm. 313:23-28.

Chobert, J. M., C. Bertrand-Harb, and M. G. Nicolas. 1988. Solubility and emulsifying properties of caseins and whey proteins modified enzymically by trypsin. J. Agric. Food Chem. 36:883-892.

Damodaran, S. 2005. Protein stabilization of emulsions and foams. J. Food Sci. 70:R54-R66.

Danviriyakul, S., D. J. McClements, E. Decker, W. W. Nawar, and P. Chinachoti. 2002. Physical stability of spray-dried milk fat emulsion as affected by emulsifiers and processing conditions. J. Food Sci. 67:2183-2189.

Dinkov, K., M. Dushkova, and N. Toshkov. 2008. Regression models for density and viscosity of ultrafiltration milk concentrates. Bulgarian J. Agric. Sci. 14:542-548.

Downton, G. E., J. L. Flores-Luna, and C. J. King. 1982. Mechanism of stickiness in hygroscopic, amorphous powders. Ind. Eng. Chem. Fundam. 21:447-451.

Drapala, K. P., M. A. Auty, D. M. Mulvihill, and J. A. O'Mahony. 2016. Improving thermal stability of hydrolysed whey proteinbased infant formula emulsions by protein-carbohydrate conjugation. Food Res. Int. In press.

Drapala, K. P., M. A. E. Auty, D. M. Mulvihill, and J. A. O'Mahony. 2015. Influence of lecithin on the processing stability of model whey protein hydrolysate-based infant formula emulsions. Int. J. Dairy Technol. 68:322-333.

Floury, J., A. Desrumaux, and J. Lardières. 2000. Effect of highpressure homogenization on droplet size distributions and rheological properties of model oil-in-water emulsions. Innov. Food Sci. Emerg. Technol. 1:127-134.

Niro, G. E. A. 2005. GEA Niro Analytical Method No. A 10a: Surface Free Fat of Powder. GEA Niro, Soeborg, Denmark.

Niro, G. E. A. 2006. GEA Niro Analytical Method No. A 11a: Particle Density, Occluded Air and Interstitial Air by Air Pycnometer. GEA Niro, Soeborg, Denmark.

Haque, M., and Y. Roos. 2004. Water sorption and plasticization behavior of spray dried lactose/protein mixtures. J. Food Sci. 69:E384-E391.

Hogan, S. A., M. H. Famelart, D. J. O'Callaghan, and P. Schuck. 2010. A novel technique for determining glass-rubber transition in dairy powders. J. Food Eng. 99:76-82.

Hogan, S. A., B. F. McNamee, E. D. O'Riordan, and M. O'Sullivan. 2001. Emulsification and microencapsulation properties of sodium caseinate/carbohydrate blends. Int. Dairy J. 11:137-144.

Hogan, S. A., and D. J. O'Callaghan. 2010. Influence of milk proteins on the development of lactose-induced stickiness in dairy powders. Int. Dairy J. 20:212-221.

Hogan, S. A., and D. J. O'Callaghan. 2013. Moisture sorption and stickiness behaviour of hydrolyzed whey protein/lactose powders. Dairy Sci. Technol. 93:505-521.

IDF (International Dairy Federation). 2001. Milk. Determination of nitrogen content-Part 2: Block digestion method (macro method). IDF Standard 20-2. International Dairy Federation, Brussels, Belgium.

Kelly, G. M., J. A. O’Mahony, A. L. Kelly, T. Huppertz, D. Kennedy, and D. J. O'Callaghan. 2015. Influence of protein concentration on surface composition and physico-chemical properties of spraydried milk protein concentrate powders. Int. Dairy J. 51:34-40.

Kelly, G. M., J. A. O'Mahony, A. L. Kelly, and D. J. O'Callaghan. 2014. Physical characteristics of spray-dried dairy powders containing different vegetable oils. J. Food Eng. 122:122-129.

Keogh, M., B. O'Kennedy, J. Kelly, M. Auty, P. Kelly, A. Fureby, and A. M. Haahr. 2006. Stability to oxidation of spray dried fish 
oil powder microencapsulated using milk ingredients. J. Food Sci. $66: 217-224$.

Lajoie, N., S. F. Gauthier, and Y. Pouliot. 2001. Improved storage stability of model infant formula by whey peptides fractions. J. Agric. Food Chem. 49:1999-2007.

Levine, H., and L. Slade. 1986. A polymer physico-chemical approach to the study of commercial starch hydrolysis products (SHPs). Carbohydr. Polym. 6:213-244.

Maher, P. G., M. A. E. Auty, Y. H. Roos, L. M. Zychowski, and M. A Fenelon. 2015. Microstructure and lactose crystallization properties in spray dried nanoemulsions. Food Struct. 3:1-11.

Maher, P. G., Y. H. Roos, and M. A. Fenelon. 2014. Physicochemical properties of spray dried nanoemulsions with varying final water and sugar contents. J. Food Eng. 126:113-119.

Mahmoud, M. I., W. T. Malone, and C. T. Cordle. 1992. Enzymatic hydrolysis of casein: Effect of degree of hydrolysis on antigenicity and physical properties. J. Food Sci. 57:1223-1229.

McCarthy, N. A., V. L. Gee, D. K. Hickey, A. L. Kelly, J. A. O'Mahony and M. A. Fenelon. 2013. Effect of protein content on the physical stability and microstructure of a model infant formula. Int. Dairy J. 29:53-59.

McCarthy, N. A., A. L. Kelly, J. A. O'Mahony, D. K. Hickey, V. Chaurin, and M. A. Fenelon. 2012. Effect of protein content on emulsion stability of a model infant formula. Int. Dairy J. 25:80-86.

Mounsey, J. S., S. A. Hogan, B. A. Murray, and D. J. O'Callaghan. 2012. Effects of hydrolysis on solid-state relaxation and stickiness behavior of sodium caseinate-lactose powders. J. Dairy Sci 95:2270-2281.

Murphy, E. G., Y. H. Roos, S. A. Hogan, P. G. Maher, C. G. Flynn, and M. A. Fenelon. 2015. Physical stability of infant milk formula made with selectively hydrolyzed whey proteins. Int. Dairy J. 40:39-46.

Murrieta-Pazos, I., C. Gaiani, L. Galet, B. Cuq, S. Desobry, and J. Scher. 2011. Comparative study of particle structure evolution during water sorption: Skim and whole milk powders. Colloids Surf. B Biointerfaces 87:1-10.

Netto, F., S. Desobry, and T. Labuza. 1998. Effect of water content on the glass transition, caking and stickiness of protein hydrolysates. Int. J. Food Prop. 1:141-161.
Omar, A. M. E., and Y. H. Roos. 2007. Water sorption and timedependent crystallization behaviour of freeze-dried lactose-salt mixtures. LWT Food Sci. Technol. (Campinas.) 40:520-528.

Palzer, S. 2010. The relation between material properties and supramolecular structure of water-soluble food solids. Trends Food Sci Technol. 21:12-25.

Písecký, J. 1997. Achieving product properties. Pages 149-191 in Handbook of Milk Powder Manufacture. Niro A/S, Copenhagen, Denmark.

Roos, Y. 1995. Characterization of food polymers using state diagrams. J. Food Eng. 24:339-360.

Roos, Y. H., and M. Karel. 1991. Plasticizing effect of water on thermal behaviour and crystallization of amorphous food models. J. Food Sci. 56:775-777.

Sheu, T. Y., and M. Rosenberg. 1995. Microencapsulation by spray drying ethyl caprylate in whey protein and carbohydrate wall systems. J. Food Sci. 60:98-103.

Shrestha, A. K., T. Howes, B. P. Adhikari, and B. R. Bhandari. 2008 Spray drying of skim milk mixed with milk permeate: Effect on drying behavior, physicochemical properties, and storage stability of powder. Drying Technology 26:239-247.

Singh, A. M., and D. G. Dalgleish. 1998. The emulsifying properties of hydrolyzates of whey proteins. J. Dairy Sci. 81:918-924.

Thomas, M. E. C., J. Scher, S. Desobry-Banon, and S. Desobry. 2004 Milk powders ageing: Effect on physical and functional properties. Crit. Rev. Food Sci. Nutr. 44:297-322.

Van den Berg, C. 1984. Description of water activity of foods for engineering purposes by means of the GAB model of sorption. Eng. Food 1:311-321.

Zhou, P., D. Liu, X. Chen, Y. Chen, and T. P. Labuza. 2014. Stability of whey protein hydrolysate powders: Effects of relative humidity and temperature. Food Chem. 150:457-462.

Zhou, Y., and Y. H. Roos. 2011. Characterization of carbohydrateprotein matrices for nutrient delivery. J. Food Sci. 76:E368-E376. 